\title{
Cellulose-Degrading Strains: their Screening and Application to Corn Straw in Low-Temperature Environments
}

\author{
Shuang Zhang, Dexin Shan*, Xiao Liu, Mengrui Sun \\ College of Resource and Environment, Northeast Agricultural University, Harbin, China
}

Received: 14 October 2017

Accepted: 26 October 2017

\begin{abstract}
Cellulose-degrading strains play an important role in cellulose degradation at low temperatures. In this study, three cellulose-degrading strains with high carboxymethyl cellulase (CMCase) activity were isolated from the soil in a low temperature environment of $10^{\circ} \mathrm{C}$. ZS-7 was Cladosporium sp, ZS-8 was Alternaria porri, and ZS-10 was Trichoderma harzianum, based on 16s rDNA gene sequence analysis. They were mixed, marked as ZS-M, and used for corn straw degradation at $15^{\circ} \mathrm{C}$ in order to determine their application properties. ZS-7, ZS-8, ZS-10, and ZS-M efficiently degraded corn straw by $45.98 \%, 47.96 \%, 34.215 \%$, and $33.56 \%$, respectively, after 30 days of stationary culture. The dynamics of CMC, $\beta$-Glucosidase, and FPA during corn straw degradation were determined. The CMCase activity of ZS-7 and ZS-8 was $31.732 \mathrm{U} / \mathrm{ml}$ and $31.111 \mathrm{U} / \mathrm{ml}$, respectively, but the enzyme activities and degradation of ZS-M were lower than the single strain because of metabolic effects that influenced the degradation process. The $\mathrm{pH}$ values of ZS-7, ZS-10, and ZS-M were particularly stable, changing from 7.08 to 7.77 during the full degradation cycle. ZS-7, ZS-8, and ZS-10 could be applied more broadly to degrade corn straw in cold regions.
\end{abstract}

Keywords: cellulose-degrading strains, corn straw, low temperatures, CMCase activity

\section{Introduction}

Agricultural residues are the most readily available source of lignocellulosic biomass in the world and, therefore, the materials of highest interest for the production of bio-fuels, chemicals, and polymeric materials. In China, an annual total of 700 million tons of agricultural residues are produced from rice, wheat, corn, and soybean, accounting for $20-30 \%$ of

*e-mail: shandexin@neau.edu.cn the world's total production [1]. Because the crystalline structure of their remains is composed of hemicellulose, cellulose, and lignin, it is very difficult to break down and degrade naturally. Most remaining straw or husk is destroyed, buried, or burned, resulting in resource waste and environmental pollution. Therefore, the question of how to use this resource effectively becomes more and more important [2] and biological pretreatments have the advantage of being less expensive and more environmentally friendly compared to mechanical, chemical, thermal, and thermo-chemical treatments [3-4]. 
In recent years, researchers have begun to pay attention to various cellulose-degrading bacteria given their fast growth, expression of multienzyme complexes, and resistance to extreme environments [56]. Microbial systems found in the gut of organisms that thrive on cellulosic biomass provide the best source [7]. There have been many studies of cellulose-degrading bacteria and they mostly concentrate on mesophilic or thermophilic bacteria. Under low temperatures, the activity of microorganisms is weak; thus, in the colder regions of China, the initial stage temperature of composting cannot increase rapidly and agricultural residues are not quickly or effectively degraded. However, few studies have focused on cellulosedegrading bacteria under low-temperature conditions [8].

The aims of this study were to: 1) isolate cellulosedegrading strains from the soil in a cold region of China, 2) directly apply the screened strains to corn straw under low temperatures and measure their degradation index, and 3) analyze their enzymatic properties to understand their potential value for applications.

\section{Materials and Methods}

\section{Collection of Samples and Medium Preparation for Limited Cultivation}

Soil samples were collected $5-10 \mathrm{~cm}$ below the surface at the Experimental Farm of Northeast Agricultural University (Harbin, China). The mixed samples were placed in a pre-sterilized bag that was stored in a refrigerator at $4^{\circ} \mathrm{C}$.

Filter paper was cut into $6-\mathrm{cm}$ long and $1-\mathrm{cm}$ wide pieces, then submerged in $1 \%(\mathrm{w} / \mathrm{v})$ acetic acid at room temperature for 24 hours, rinsed with distilled water to neutralize $\mathrm{pH}$, and oven-dried at $80^{\circ} \mathrm{C}$.

The filter enrichment culture medium was $1.0 \mathrm{~g} / 1$ $\mathrm{KH}_{2} \mathrm{PO}_{4}, 2.5 \mathrm{~g} / 1 \mathrm{NaNO}_{3}, 0.3 \mathrm{~g} / 1 \mathrm{MgSO}_{4} \cdot 7 \mathrm{H}_{2} \mathrm{O}, 0.1 \mathrm{~g} / 1$ $\mathrm{CaCl}_{2}, 0.1 \mathrm{~g} / 1 \mathrm{NaCl}, 0.01 \mathrm{~g} / 1 \mathrm{FeCl}_{3}$, and $10 \mathrm{~g} / 1$ treated filter paper. The medium was autoclaved at $121^{\circ} \mathrm{C}$ for 30 minutes. A $1 \mathrm{~g}$ soil sample was inoculated into a $100 \mathrm{ml}$ flask along with $50 \mathrm{ml}$ of medium. Limited cultivation was carried out by way of horizontal shaking movement $(120 \mathrm{rpm})$ in the dark at $10^{\circ} \mathrm{C}$ with three replications. After a 7-day cultivation, $5 \mathrm{ml}$ of well-blended culture fluid was transferred to a new $100 \mathrm{ml}$ flask with $50 \mathrm{ml}$ of medium and incubated under the same conditions. During the process, successive transfers were continued every 7 days, and replications without effective degradation capacity were eliminated. Fifteen weeks of samples were preserved for further screening.

\section{Isolation and Screening}

The samples were made into five dilutions of sterile water: $10^{-3}, 10^{-4}, 10^{-5}, 10^{-6}$, and $10^{-7} .100 \mu \mathrm{l}$ of each dilution was spread onto the isolation medium $\mathrm{CMC}$ plate, which consisted of: $15 \mathrm{~g} / 1 \mathrm{CMC}-\mathrm{Na}, 1 \mathrm{~g} / 1 \mathrm{NH}_{4} \mathrm{NO}_{3}$, $0.5 \mathrm{~g} / 1 \mathrm{MgSO}_{4} \cdot 7 \mathrm{H}_{2} \mathrm{O}, 1 \mathrm{~g} / 1 \mathrm{KH}_{2} \mathrm{PO}_{4}, 1 \mathrm{~g} / 1$ yeast extract, and $20 \mathrm{~g} / 1$ agar. The $\mathrm{CMC}$ plates were placed in an incubator at $10^{\circ} \mathrm{C}$ for one week. The morphologically identified single colonies were selected with an inoculating needle and inoculated onto CMC plates. The purified isolates were then preserved at $4^{\circ} \mathrm{C}$ until needed. Stock isolates were stored at $-80^{\circ} \mathrm{C}$.

Strains were screened for cellulose activity using a Congo-red stain agarose plate technique [9] with CMC plates of isolation medium. The hydrolyzing zones were visible around the strains, indicating that the strains exhibited potential for degrading CMC.

Strains were further screened by determining carboxymethyl cellulase (CMCase) activity. Strains were then removed and placed into the filter enrichment culture medium and cultivation was carried out with a horizontal shaking movement $(120 \mathrm{rpm})$ in the dark at $10^{\circ} \mathrm{C}$ for 3 days. The fermentation broth was centrifuged at 5,000 rpm for 15 minutes. The resulting supernatant was used for enzyme analysis, and the enzyme activities were determined by measuring the release of reducing glucose from the substrates $1 \%(\mathrm{w} / \mathrm{v})$ sodium carboxymethyl cellulose. Crude enzyme samples were obtained from the filtrates of the filter enrichment medium cultures. The enzyme activities were analyzed using the 3,5-dinitrosalicylic acid (DNS) method previously described [10]. All assays were performed in triplicate with negative controls. One unit of enzyme activity was defined as the amount of cellulase-produced glucose assuming 1\%-degraded $1 \mathrm{ml}$ enzyme sample substrates at $50^{\circ} \mathrm{C}$ and $4.8 \mathrm{pH}$.

\section{Identifying Low-Temperature Cellulose-Degrading Strains}

The identification of strains was accomplished by observing the results of biochemical reactions and $16 \mathrm{~s}$ or $18 \mathrm{~s}$ rDNA sequencing. The DNA extraction, $16 \mathrm{~s}$ or 18s PCR amplification, and 3,730 sequencing were determined by Beijing Huada Gene Company (Beijing, PR China). The resulting sequences were compared with those in the National Center for Biotechnology Information (NCBI) GenBank using the BLAST program [11]. A phylogenetic tree was constructed with the neighbor-joining method in the MEGA program ver. 4.0. [12].

\section{Antagonistic Experiment}

The dominant strains cross on the isolation medium plate but do not overlap by a sterile inoculation ring. Each sample was replicated three times with a single strain control. And incubated in a thermostatic incubator at $10^{\circ} \mathrm{C}$ until significant changes in colonies could be observed. The strains, under normal growth, proved not to be antagonistic; otherwise, antagonistic. 


\section{Degradation of Corn Straw}

\section{Corn Straw and Degradation of Corn Straw}

Corn straw was obtained from the Experimental Farm of Northeast Agricultural University (Harbin, China). The straw, which carried no diseases or contaminating insects, was air dried. A whole plant, including leaves and stalks, was cut into $1 \times 3 \mathrm{~cm}$ pieces, then submerged in $1 \%(\mathrm{w} / \mathrm{v})$ sodium hydroxide at room temperature for 24 hours, washed with distilled water to neutral $\mathrm{pH}$, and oven-dried at $60^{\circ} \mathrm{C}$.

The corn straw culture medium was $1.0 \mathrm{~g} / 1 \mathrm{KH}_{2} \mathrm{PO}_{4}$, $2.5 \mathrm{~g} / 1 \mathrm{NaNO}_{3}, 0.3 \mathrm{~g} / 1 \mathrm{MgSO}_{4} \cdot 7 \mathrm{H}_{2} \mathrm{O}, 0.1 \mathrm{~g} / 1 \mathrm{CaCl}_{2}, 0.1$ $\mathrm{g} / 1 \mathrm{NaCl}, 0.01 \mathrm{~g} / 1 \mathrm{FeCl}_{3}$, and $10 \mathrm{~g} / 1$ treated corn straw.

The dominant strains were cultured separately and all non-antagonized strains were mixed and cultured. A seed volume of $10 \%$ was inoculated into a $75 \mathrm{ml}$ corn straw culture medium, and the medium was cultured under static conditions at $15^{\circ} \mathrm{C}$. Fermentation lasted for 30 days and samples were taken to obtain corn straw degradation on days zero (immediately after inoculation), three, six, nine, 12, 15, 18, 21, 24, 27, and 30. Each sample was replicated three times with an uninoculated control. Corn straw degradation was expressed as a percentage of the losses.

\section{Enzyme Activities}

Carboxymethyl cellulase (CMCase), $\beta$-Glucosidase ( $\beta$-Gase), and total cellulase activity (filter paper activity, FPA) were determined by measuring the release of reducing glucose from the substrates $1 \%(\mathrm{w} / \mathrm{v})$ sodium carboxymethylcellulose, $1 \%$ (w/v) salicylic acid, and one piece of treated filter paper [13-14], respectively. Crude enzyme samples were obtained from the filtrates of the cultures. The enzyme activities were also analyzed using the 3,5-dinitrosalicylic acid (DNS) method previously described. All assays were performed in triplicate with negative controls.

\section{Determining OD (Optical Density) and pH of Fermenta- tion Broth during Degradation of Corn Straw}

The OD of the sample was determined with a UV spectrophotometer of UV-1800 at $540 \mathrm{~nm}$, and $\mathrm{pH}$ was determined using a compact $\mathrm{pH}$ meter (model PHS25).

\section{Degradation of Filter Paper}

The dominant strains were cultured separately and all non-antagonized strains were mixed and cultured. To determine the capacity of cellulose degradation for pure and mixed strains, filter paper was substituted for corn straw as the carbon source, and microbes were cultured under the same conditions described above. Cultured samples (including broth and remaining solids) were transferred to $100 \mathrm{ml}$ centrifuge tubes and centrifuged at 5,000 rpm for 15 minutes. Precipitates were washed with acetic acid, nitric acid reagent [15] and water, to remove noncellulosic materials, and centrifuged at $5000 \mathrm{r} / \mathrm{min}$ for 15 minutes. Precipitates were dried at $60^{\circ} \mathrm{C}$ and weighed, and the filter paper degradation was expressed as a percentage of the losses.

\section{Results and Discussion}

Isolating Strains and Determining Strain Cellulose-Degradation at Low Temperature

The cellulose-degrading strains that accelerated corn straw degradation under a low-temperature environment were successfully selected. Survival and catabolic activity of introduced microorganisms were two key factors for successful introduction into the soil [16]. In the present study, soil from the field was used as a source of cellulose-degrading strains in the laboratory under low temperature. A total of 13 strains were isolated from the soil sample. Through a series of screenings, there were only three strains (ZS-7, ZS-8, and ZS-10) that produced significant amounts of CMCase activity under low-temperature conditions. The results of Congo-red staining show that D/d of ZS-7, ZS-8, and ZS-10 reached 6.5, 6, and 7, respectively (Table 1). The CMC of ZS-7, ZS-8, and ZS-10 also reached $81.225 \mathrm{U} / \mathrm{ml}, 65.9 \mathrm{U} / \mathrm{ml}$, and $101.864 \mathrm{U} / \mathrm{ml}$, which were higher than those of the other strains (Fig. 1). These two results seem to be related. These isolates were then kept in a $50 \%$ glycerol solution at $-80^{\circ} \mathrm{C}$ as the stock culture for further studies.

Table 1. Experimental results of Congo-red staining.

\begin{tabular}{|c|c|c|c|}
\hline Strain & $\mathrm{d}(\mathrm{cm})$ & $\mathrm{D}(\mathrm{cm})$ & $\mathrm{D} / \mathrm{d}$ \\
\hline ZS-1 & 0.4 & 0.8 & 2 \\
\hline ZS-2 & 0.8 & 1.7 & 2.125 \\
\hline ZS-3 & 1.6 & 2.2 & 1.375 \\
\hline ZS-4 & 0.2 & 0.45 & 2.25 \\
\hline ZS-5 & 0.5 & 0.9 & 1.8 \\
\hline ZS-6 & 0.4 & 0.9 & 2.25 \\
\hline ZS-7 & 0.2 & 1.3 & 6.5 \\
\hline ZS-8 & 0.3 & 1.8 & 6 \\
\hline ZS-9 & 0.5 & 1.2 & 2.4 \\
\hline ZS-10 & 0.2 & 1.4 & 7 \\
\hline ZS-11 & 0.2 & 0.6 & 3 \\
\hline ZS-12 & 0.3 & 0.7 & 2.33 \\
\hline ZS-13 & 0.5 & 0.9 & 1.8 \\
\hline
\end{tabular}

Note: d, Colony diameter; D, Hydrolyzing zones diameter 


\section{Cellulase}

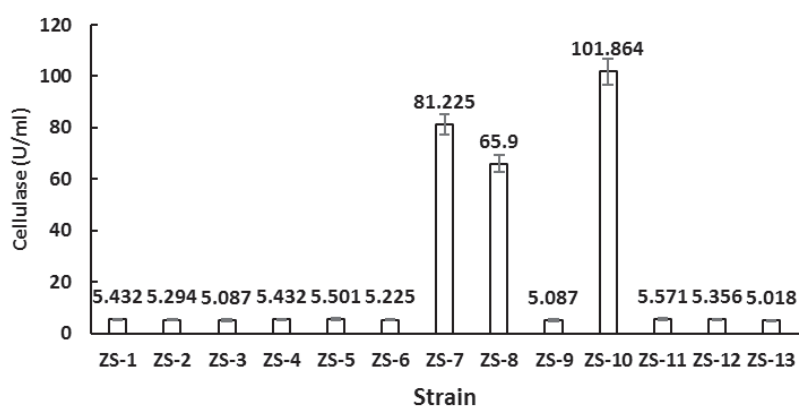

Fig. 1. CMC activities of the strains.

Identifying Low-Temperature

Cellulose-Degrading Strains

The BLAST results of sequences showed that strain ZS-7 was Cladosporium sp, ZS-8 was Alternaria porri, and ZS-10 was Trichoderma harzianum. Fig. 2 indicates the relative positions of clones of ZS-7, ZS-8, and ZS-10, as inferred by the NCBI.

\section{Antagonistic Experiment}

By observing and recording the growth of the strains, this study found that ZS-7, ZS-8, and ZS-10 were not antagonized relative to each other; therefore, they can be mixed and cultured for further studies and marked as ZS-M.

\section{Degradation of Corn Straw and Filter Paper}

The whole experiment was carried out at $15^{\circ} \mathrm{C}$, to ensure low-temperature conditions, and lasted 30 days static cultivation in order to more closely resemble the actual natural degradation environment. The corn straw degradation of ZS-7, ZS-8, ZS-10, and ZS-M was rapid in the early stages, increasing by $18.64 \%, 16.84 \%$, $11.08 \%$, and $14.9 \%$, respectively, within six days. After that, the degradation ratio gradually increased by $45.98 \%, 47.96 \%, 34.215 \%$, and $33.56 \%$, respectively, after fermentation for 30 days at $15^{\circ} \mathrm{C}$ (Fig. 3). The filter paper decreased by $41.085 \%, 47.55 \%, 29.505 \%$, and $30.88 \%$ under the same conditions.

There are many similar studies but none of them maintained such a low-temperature environment. The composite microbial system of $\mathrm{MC1}$ efficiently degraded corn stalks at $50^{\circ} \mathrm{C}$, and Rhodococcus sp. MI 2 degraded cellulose at $25^{\circ} \mathrm{C}$ [17-18]. The corn straw was cut into $1 \times 3 \mathrm{~cm}$-long pieces that could be returned directly to the field. The longer the corn straw, the more difficult the degradation of strains, so, through this experiment, we can further understand the strains' degradation abilities and the data of the entire fermentation process for practical applications. Li and Feng, et al., also examined screening cellulose-degrading strains under low-temperature conditions, but they optimized the fermentation conditions of carbon and nitrogen sources instead of using corn straw. The experiment lasted up to 30 days in order to obtain more stable and effective data and ensure better observation of the degradation

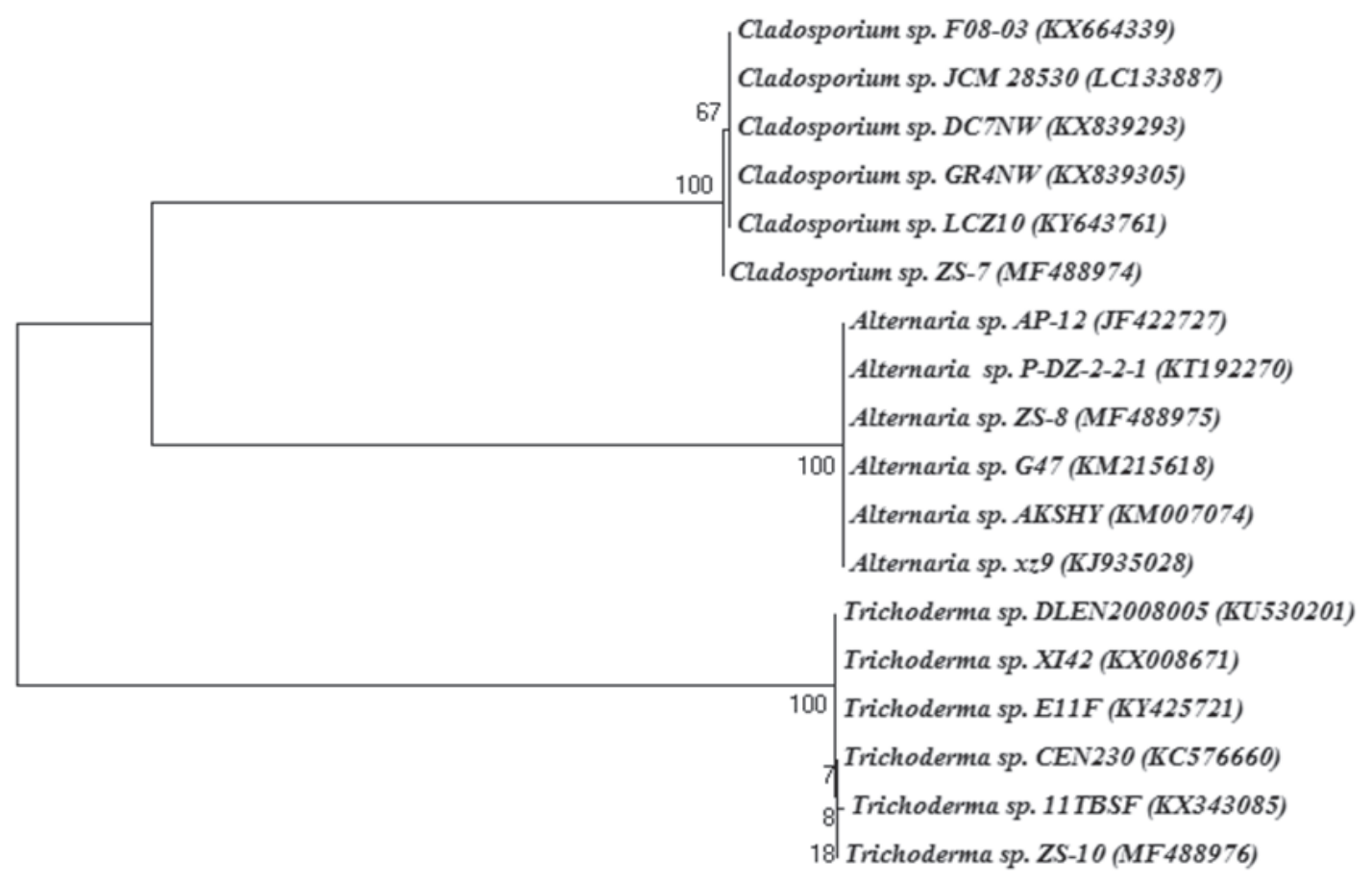

0.05

Fig. 2. Phylogenetic tree showing the relative positions of clones of ZS-7, ZS-8, and ZS-10, as inferred by the NCBI. 
a) 2S-7 DEGRADATION ROTIO

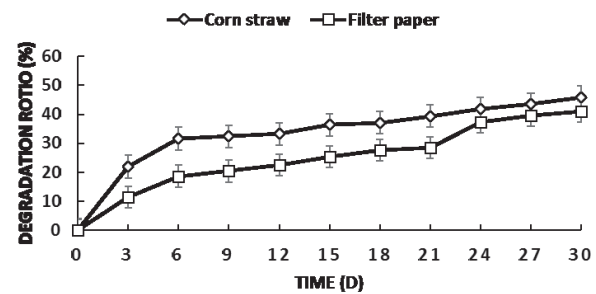

c) ZS-10 DEGRADATION RATIO

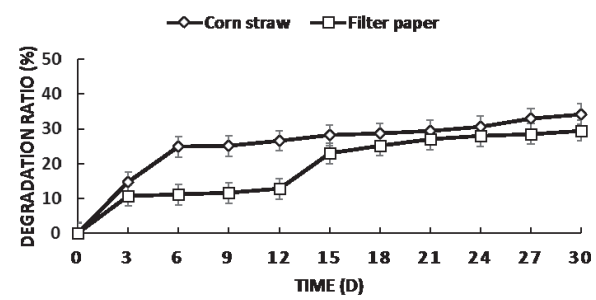

Fig. 3. Corn straw and filter paper degradation ratios.

process. Sheykhnazari, Tabarsa, Ashori, Shakeri, and Golalipour also reported that cellulose production increased with time, but no increase was observed after 14 days of incubation [19]. Therefore, we can continue to observe the entire process of degradation and changes in various indicators so that more relevant analyses can be obtained.

Corn straw was degraded effectively after fermenting for 30 days and the degradation ratio of ZS- 8 reached $47.96 \%$. Due to the different materials used, the degradation results varied. The filter paper degradation ratio reached $47.55 \%$ by ZS-8. From Figs 3(a, c, and d), we can see that the remaining strains also have a higher degradation rate, but the degradation ratio of ZS-M was lower than the single strains ZS-7, ZS-8, and ZS-10. This phenomenon shows that, even if the strains were

\section{b) ZS-8 DEGRADATION RATIO}

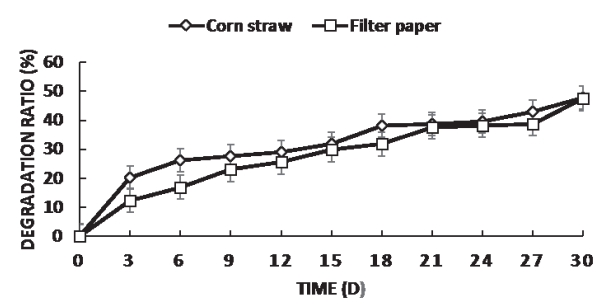

d) ZS-M DEGRADATION RATIO

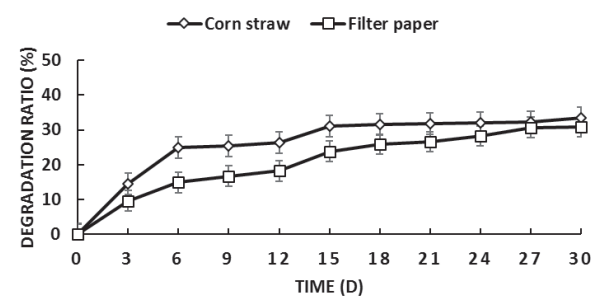

from the same source and lacked antagonistic response, it does not mean that the effect of a single mixed strain will improve degradation; rather, the opposite is true because it possesses a certain stability. According to Fig. $5 \mathrm{~b}$ ), the fermentation $\mathrm{pH}$ of $\mathrm{ZS}-8$ gradually reduced to 5.79 , which was likely due to the production of a large number of acidic metabolites and their influence on the degradation process. There are many studies about the screening of microbial consortia, including OEM1, for simultaneous degradation of lignocellulose and chlorophenols [20], but there have not been any results pertaining to the effect comparisons of single and mixed strains. The present study effectively made up for these (and similar) problems, providing a basis for further research.

a) ZS-7 ENZYME ACTIVITIES

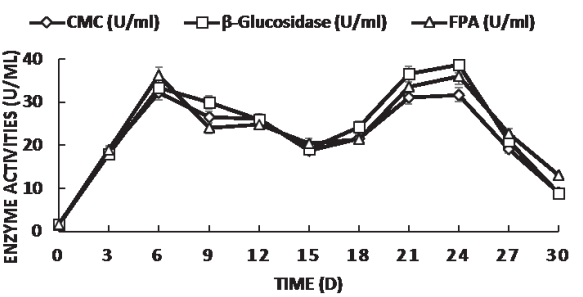

(c) ZS-10 ENZYME ACTIVITIES

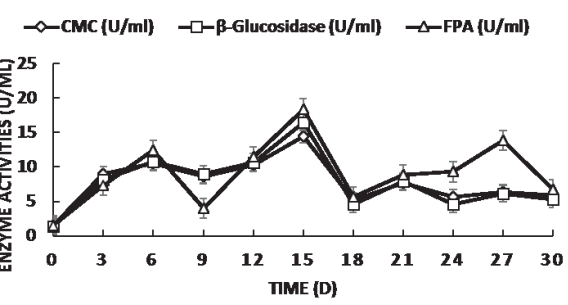

b) ZS-8 ENZYME ACTIVITIES

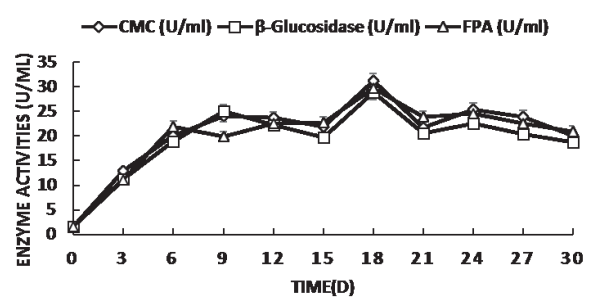

d) ZS-M ENZYME ACTIVITIES

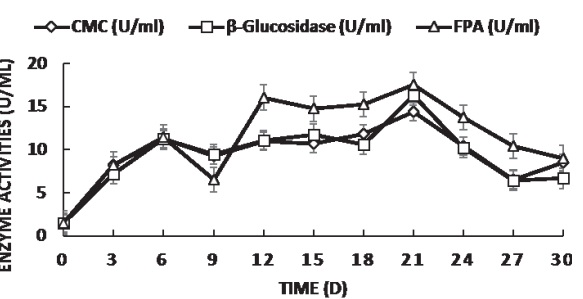

Fig. 4. Enzyme activities of carboxymethyl cellulase activity (CMC), $\beta$-glucosidase activities ( $\beta$-Gase), and filter paper enzyme activities (FPA). 


\section{Enzyme Activities}

The dynamics of CMC, $\beta$-Glucosidase, and FPA during 30 days of corn straw degradation are shown in Fig. 4. The trends of all enzyme activities are basically the same. The enzyme activities increased dramatically during the first six days of fermentation for all strains.

The enzyme activities of ZS-7 showed an initial increase and then tended to be stable. The CMC, $\beta$-Glucosidase, and FPA gradually increased by $31.732 \mathrm{U} / \mathrm{mL}, 38.704 \mathrm{U} / \mathrm{mL}$ and $35.943 \mathrm{U} / \mathrm{mL}$, respectively. Eventually, they reached peak values on day 24. After that, enzyme activities showed a sharp decrease by $1.523 \mathrm{U} / \mathrm{ml}, 1.564 \mathrm{U} / \mathrm{ml}$, and $1.633 \mathrm{U} / \mathrm{ml}$ after 30 days of fermentation (Fig. 4a).

The enzyme activity dynamics of ZS-8 were relatively stable, as they increased dramatically with CMC, $\beta$-Glucosidase, and FPA of $24.070 \mathrm{U} / \mathrm{ml}$, $25.036 \mathrm{U} / \mathrm{ml}$, and $19.859 \mathrm{U} / \mathrm{ml}$, respectively, after 9 days of incubation. The values increased slowly during the following days until it peaking on day 18 at $31.111 \mathrm{U} / \mathrm{ml}$, $28.833 \mathrm{U} / \mathrm{ml}$, and $29.661 \mathrm{U} / \mathrm{ml}$ (Fig. 4b).

The enzyme activities of ZS-10 and ZS-M were much lower than ZS-7 and ZS-8. The CMC, $\beta$-Glucosidase, and FPA for ZS-10 peaked at 14.475 U/ml, $16.477 \mathrm{U} / \mathrm{ml}$, and $18.410 \mathrm{U} / \mathrm{ml}$ on day 15 (Fig. 4c). Finally, the CMC, $\beta$-Glucosidase, and FPA for the ZS-M peaked at $14.406 \mathrm{U} / \mathrm{ml}, 16.270 \mathrm{U} / \mathrm{ml}$, and $17.512 \mathrm{U} / \mathrm{ml}$ on day 21 , then gradually decreased following fermentation (Fig. 4d).

All of them showed a tendency to increase first, then either decrease or remain stable. From Figs 4(ad) we can see that the enzymatic activities of ZS-7 and ZS-8 were significantly higher than those of ZS-10 and ZS-M. They produced noticeable carboxymethyl cellulase, $\beta$-glucosidase, and total cellulase activity during the entire culture process. The enzymes are functional in their degradation and, combined with their degradation rate, we can infer that the higher the enzyme activity, the stronger the degradation ability.

\section{Changes in $\mathrm{pH}$ during Corn Straw Degradation}

The $\mathrm{pH}$ of the fermentation broth during corn straw degradation is also shown in Fig. 5. The $\mathrm{pH}$ values of ZS-7, ZS-10, and ZS-M were particularly stable. During the whole fermentation process, the $\mathrm{pH}$ of $\mathrm{ZS}-7$ ranged from 7.08 to 7.70 , the $\mathrm{pH}$ of $\mathrm{ZS}-10$ ranged from 7.12 to 7.67 , and the $\mathrm{pH}$ value ranged from 7.51 to 7.77 of ZS-M. On the other hand, the $\mathrm{pH}$ of ZS-8 gradually decreased to 5.79 on day 30 .

The $\mathrm{pH}$ of ZS-7, ZS-10, and ZS-M changed from 7.08 to 7.77 during the degradation process, itself influenced by the $\mathrm{pH}$ of the soil, indicating that there were certain degrees of self-discipline and stability. A neutral $\mathrm{pH}$ niche was available, which was favorable to the survival and catabolic activity of introduced microorganisms [21].

\section{Changes in OD during Corn Straw Degradation}

The OD was determined on days $0,3,6,9,12,15,18$, 21, 24, 27, and 30. Results of the OD in Fig. 5 show that mycelial biomass increased substantially in ZS-7, ZS8, ZS-10, and ZS-M. The peak values of ZS-7 and ZS-8 occurred in later stages, ZS-7 peaked on day 24 at 0.333 , and ZS-8 peaked at 0.536 on day 27 . The dynamics of ZS-7 and ZS-8 showed a tendency to increase first and then decrease gradually. But the tendency of ZS-10 and the mixed strains were to increase first and then become stable. ZS-10 peaked on day 15 at 0.548 and ZS-M peaked at 0.597 on day 24 .

The OD values clearly show the dynamic changes in the number of strains, and the rise of OD values means the strains grew and increased. From the results of OD and the three enzyme activities, we can infer that the
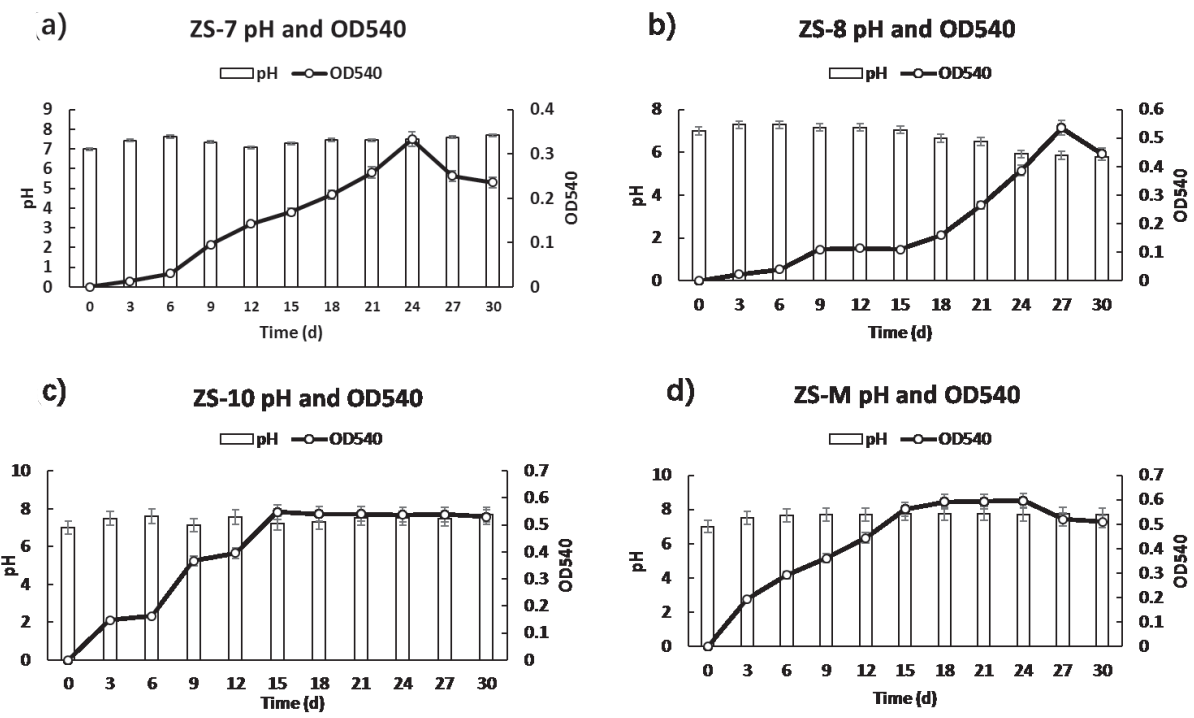

Fig. 5. Changes in $\mathrm{OD}$ and $\mathrm{pH}$ during degradation of corn straw. 
strains propagated vigorously and need a lot of energy, not only to produce the higher enzyme activity, but also degrade corn straw effectively.

\section{Conclusions}

ZS-7, ZS-8, and ZS-10 are low-temperature $\left(15^{\circ} \mathrm{C}\right)$ cellulose-degrading strains. Their corn straw degradation ratios are able to gradually increase to $45.98 \%, 47.96 \%$, and $34.215 \%$, respectively, after fermentation for 30 days at this temperature. They are relatively stable and exhibit effective degradation. We recommend further study about its application in corn straw degradation at low temperatures.

\section{Acknowledgements}

This work was supported by the National Science and Technology Major Research, Project No. 2012ZX07201003-003.

\section{References}

1. XU X., XU Z., SONG S., LIN M. Lignocellulose degradation patterns, structural changes, and enzyme secretion by Inonotus obliquus on straw biomass under submerged fermentation. Bioresource Technology, 241, 2017.

2. GUO H., CHANG J., YIN Q., WANG P., LU M., WANG X., DANG X. Effect of the combined physical and chemical treatments with microbial fermentation on corn straw degradation. Bioresource Technology, 148 (5), 361, 2013.

3. SINDHU R., BINOD P., PANDEY A. Biological pretreatment of lignocellulosic biomass - an overview. Bioresource Technology, 199, 76, 2015.

4. LIANG Y.S., YUAN X.Z., ZENG G.M., CHEN L.H., ZHONG H., HUANG D.L., TANG L., ZHAO J.J. Biodelignification of rice straw by Phanerochaete chrysosporium in the presence of dirhamnolipid. Biodegradation 21, 615, 2010.

5. SOARES FL JR., MELO I.S., DIAS A.C, ANDREOTE F.D. Cellulolytic bacteria from soils in harsh environments. World Journal of Microbiology \& Biotechnology, 28 (5), 2195, 2012.

6. MARJAMAA K., TOTH K., BROMANN P.A, SZAKACS G., KRUUS K. Novel Penicillium cellulases for total hydrolysis of lignocellulosics. Enzyme \& Microbial Technology, 52 (6-7), 358, 2013.

7. AND R.J.D, DILLON V.M. The gut bacterla of insects: Nonpathogenic Interactions. Annual Review of Entomology, 49 (1), 71, 2004.

8. LI D., FENG L., LIU K., CHENG Y., HOU N., LI C. Optimization of cold-active CMCase production by psychrotrophic Sphingomonas, sp. FLX-7 from the cold region of China. Cellulose, 23 (2), 1335, 2016.
9. DUNCAN S.M, FARRELL R.L, THWAITES J.M, HELD B.W, ARENZ B.E, JURGENS J.A, BLANCHETTE R.A. Endoglucanase-producing fungi isolated from Cape Evans historic expedition hut on Ross Island, Antarctica. Environmental Microbiology, 8 (7), 1212, 2006.

10. GUO P., ZHU W., WANG H., LU Y., WANG X., ZHENG D., CUI Z. Functional characteristics and diversity of a novel lignocelluloses degrading composite microbial system with high xylanase activity. Journal of Microbiology \& Biotechnology, 20 (2), 254, 2010.

11. JEANMOUGIN F., THOMPSON J.D, GOUY M., HIGGINS D.G, GIBSON T.J. Multiple sequence alignment with Clustal X. Trends in Biochemical Sciences, 23 (10), 403, 1998.

12. TAMURA K., DUDLEY J., NEI M., KUMAR S. MEGA4: Molecular evolutionary genetics analysis (MEGA) software version 4.0. Molecular Biology and Evolution, 24 (24), 1596, 2007.

13. KUMAR S., SHARMA H.K, SARKAR B.C. Effect of substrate and fermentation conditions on pectinase and cellulase production by Aspergillus niger, NCIM 548 in submerged (SmF) and solid state fermentation (SSF). Food Science \& Biotechnology, 20 (5), 1289, 2011.

14. CUI Y.X, LIU J.J, LIU Y., CHENG Q.Y, YU Q., CHEN X., REN X.D. Protoplast fusion enhances lignocellulolytic enzyme activities in Trichoderma reesei. Biotechnology Letters, 36 (12), $2495,2014$.

15. UPDEGRAFF D.M. Semimicro determination of cellulose in biological materials. Analytical Biochemistry, 32 (3), 420, 1969.

16. JUHANSON J., TRUU J., HEINAU E., HEINARU A. Survival and catabolic performance of introduced Pseudomonas strains during phytoremediation and bioaugmentation field experiment. Fems Microbiology Ecology, 70 (3), 446, 2009.

17. TANSKUL S., AMORNTHATREE K., JATURONLAK N. A new cellulose-producing bacterium, Rhodococcus sp. MI 2: screening and optimization of culture conditions. Carbohydrate Polymers, 92 (1), 421, 2013.

18. GUO P., WANG X.F, ZHU W.B, YANG H.Y, CHENU X., CUI Z.J. Degradation of corn stalk by the composite microbial system of MC1.Journal of Environmental Science (English Edition), 20 (1), 109, 2008.

19. SHEYKHNAZARI S., TABARSA T., ASHORI A., SHAKERI A., GOLALIPOUR M. Bacterial synthesized cellulose nanofibers; Effects of growth times and culture mediums on the structural characteristics. Carbohydrate Polymers, 86 (3), 1187, 2011.

20. LIANG J., XIANG P., YIN D., Li B., WANG D., LIN Y. Screening of a microbial consortium for highly simultaneous degradation of lignocellulose and chlorophenols. Bioresource Technology, 190 (43), 381, 2015.

21. PEI-PEI L.I., WAMG X.J, YUAN X.F, WANG X.F, CAO Y.Z, CUI Z.J. Screening of a Composite Microbial System and Its Characteristics of Wheat Straw Degradation. Journal of Integrative Agriculture (English Edition), 10 (10), 1586, 2011. 
